\title{
Strategi Para Tokoh Agama Dalam Mendidik Kerukunan Eksternal dan Implikasinya terhadap Keutuhan NKRI di Bangka Belitung
}

\author{
Suparta \\ Program Pascasarjana \\ IAIN Syaikh Abdurrahman Siddik Bangka Belitung \\ Bangka, Indonesia \\ partasuparta23@yahoo.co.id
}

\begin{abstract}
There are three strategies carried out by religious leaders in educating religious harmony in their people, especially those related to external harmony. First, the strategy of educating people in the internal harmony of religious people. In this case all religious leaders each agreed to foster their people to live in harmony and peace. Of course this direction is in accordance with the teachings of the respective books. Second, the strategy of educating their people to get along with other fellow religions. They try their best so that every people always respect and respect other religions, they cannot force the will of their religion, they must not mutilate each other and also not harm other religious people. This is also stated in the scriptures in each religion. Third, the strategy of educating the people to get along well with the government. all religious teachings order that they always have good relations and respect for their government. This is because all realize that we live in the same country, namely the Indonesian state in one power and government. So respecting, respecting and fulfilling government rules is a must. The strategy to maintain the integrity of the NKRI was also agreed upon by all religious leaders. They agreed that if the basis of the Indonesian state is Pancasila, don't change it again. This is because so far what can unite all religious teachings in Indonesia is Pancasila. For this reason the NKRI is intact and will remain intact if all religions maintain the Pancasila.
\end{abstract}

Keywords: strategy, religious leaders, integrity of NKRI

Abstrak

Ada tiga Strategi yang dilakukan oleh para tokoh Agama dalam mendidik kerukuan beragama pada umatnya khususnya yang berhubungan dengan kerukunan secara eksternal.

Pertama, strategi mendidik umat dalam kerukunan internal umat beragama. Dalam hal ini semua para tokoh agama masing-masing sepakat membina umatnya agar hidup rukun dan damai. Tentunya arahan ini sesuai dengan ajaran kitabnya masing-amsing. Kedua, strategi mendidik umatnya agar rukun dengan sesama agama yang lainnya. Mereka berusaha maksimal agar setiap umatnya selalu menghargai dan menghormati agama yang lainnya, tidak boleh mamaksa kehendak agamanya, tidak boleh saling menjelek-jelekkan gama yang lain dan juga tidak boleh menyakiti umat agama lainnya. Hal ini pun tercantum dalam kitab suci disetiap agama masing-masing. Ketiga, strategi mendidik umatnya agar rukun dengan 
pemerintah. semua ajaran agama memerintahkan agar selalu berhubungan baik dan menghormati pemerintahnya. Hal ini disebabkan semuanya menyadari bahwa kita hidup dinegara yang sama yaitu negara Indonesia dalam satu kekuasaan dan pemerintahan. Maka menghormati, menghargai dan mamtuhi aturan pemerintah adalah sebuah keharusan. Strategi untuk menjaga keutuhan NKRI juga disepakati oleh semua tokoh agama. Mereka sepakat jika dasar negara Indonesia adalah Pancasila, jangan dirubah lagi. Hal ini disebabkan selama ini yang dapat menyatukan semua ajaran agama yang ada di Indonesia adalah Pancasila. Untuk itu NKRI menjadi utuh dan akan tetap utuh jika semua agama menjaga pancasila.

Kata Kunci: strategi, tokoh agama, keutuhan NKRI

\section{A. Pendahuluan}

Agama pada posisinya adalah sebagai landasan normatif dalam menjalankan sebuah fungsi Negara, Negara adalah kekuasaan yang harus menaungi agama dan pemeluknya sehingga akan terjalin dan tercipta kerukunan antar umat beragama dan kerukunan antar setiap etnis dalam Negara. Agama membutuhkan negara sebagai instrumen dalam melestarikan dan mengembangkan agama. Begitu juga sebaliknya, negara memerlukan agama, karena agama juga membantu negara dalam pembinaan moral, etika, dan spiritualitas. Hal ini kemudian ditegaskan dengan pernyataan bahwa pada setiap agama memiliki keyakinan dan ajaran yang berbeda-beda antara satu dengan lainnya, akan tetapi pada dasarnya bahwa setiap agama tersebut mengajarkan tentang sikap saling menghargai, saling menghormati, serta dapat hidup berdampingan secara damai dengan pemeluk agama lainnya, maka negara dan masyarakat berkewajiban untuk mengembangkan kehidupan beragama dengan penuh rasa toleransi dan rasa menghargai berdasarkan nilai-nilai kemanusiaan yang beradab. ${ }^{1}$

Ada relevansi yang jelas kemudian antara agama dan kehidupan modern. Ditengah keberagaman penganut agama dan jenis agama yang dianut oleh masyarakat tentunya akan menimbulkan beberapa perbedaan dan ekses akibat dominasi ilmu dan teknologi ditambah lagi perbedaan dalam pelaksanaannya, lembaganya dan bentuk-bentuk pendidikan pada masing-masing agama. Disinilah kemudian menurut Nurcholish Madjid titik penekanan yang harus diperkuat yaitu ada rasa toleransi, sikap menghargai dan sikap agama dan kehidupan modern. ${ }^{2}$

Point terpenting dalam mengembangkan kehidupan beragama dan bernegara yang baik dengan penuh rasa toleransi dan rasa menghargai berdasarkan nilai-nilai kemanusiaan yang adil dan beradab adalah para penyelenggara Negara (daerah) dan peran para ulama, para da'i, tokoh-tokoh agama pada semua agama yang ada dalam berdakwah dan dalam mengembangkan pendidikan keagamaan. Dalam konteks inilah peran dan andil mereka dituntut dalam mengharmonisasikan dan mentoleransikan antar kelompok dan antar agama. Maka, diperlukan pemetaan

${ }^{1}$ Lihat, Heri herdiawanto dan Jumanta Hamdayama, Cerdas, Kritis, dan Aktif Berwarganegara, (Jakarta: Erlangga, 2010), hlm.168

${ }^{2}$ Lihat, Nurcholish madjid, Islam Kemodernan dan Keindonesiaan, (Bandung: PT. Mizan Pustaka, 2008), hlm. 115 
dan profil yang jelas bagi masing-masing, baik dilihat dari aspek pelakunya, ajarannya, materinya, lembaganya, pendidikannya, pengikutnya ataupun doktrindoktrin yang diajarkan. Berangkat dari hal inilah kemudian perlunya pemetaan pendidikan keagamaan antar masing-masing agama yang ada khususnya di Provinsi Kepulauan Bangka Belitung. Hal ini untuk mengetahui bagaimana kerukunan umat beragama yang ada di Bangka Belitung khususnya yang berkaitan dengan hubungan keagamaan secara eksternal.

\section{B. Strategi Tokoh Agama Islam mendidik Toleransi Eksternal}

Menurut Drs. Rahmansyah, $\mathrm{MM}^{3}$ perwakilan pengurus FKUB dari Agama Islam, ia mengatakan bahwa ada tiga strategi yang selama ini digunakan agar antar umat beragama bisa hidup rukun, umummnya di Indonesia dan khususnya di Kabupaten Belitung. Adapun ketiga strategi tersebut adalah;

Pertama, Merangkul dan melibatkan semua tokoh agama untuk ikut andil dalam membina dan menjaga kerukunan umat beragama. Seperti, mengajak sama sama seluruh tokoh agama datang ke desa desa dengan program FKUB masuk Desa. Ketika semua tokoh agama datang ke desa-desa inilah kita akan mengetahui tentang berbagai kebutuhan para umat beragama sekaligus mencari solusi bersama jika ada sumber-sumber komplik di daerah pedesaan.

Selain itu, sebagai wujud nyata kerukunan maka para tokoh agama juga menggunakan cara mengapresiasi setiap ada hari raya besar di setiap agama. Seperti yang sudah dilakukan selama ini setiap hari raya Idul fitri, maka kami merangkul dan melibatkan semua tokoh agama untuk ikut serta merayakannya. Disaat umat Islam solat Id maka para tokoh agama mengikutinya dengan khidmat dan menyaksikan langsung solat Idul fitri di Lapangan. Setelah selesai maka semua tokoh agama non muslim seperti Pastor, Pendeta, Pandeta, Biksu, Rohaniawan Konghucu ikut bersalam salaman dengan umat Islam. Bahkan salah satu dari tokoh non muslim tersebut ada yang menyiapkan konsumsi yang dibagikan kepada umat islam yang baru saja menunaikan solat Idul Fitri. Semua ini dilakukan sebagai wujud rasa saling asah asih dan asuh sesama umat beragama agar keharmonisan dalam menjalankan keyakinan bergama menjadi nyaman dan damai.

Kedua, berusaha menekan sekecil apapaun riak-riak komplik antar umat beragama. Misalnya baru-baru ini ada kesalahpahaman atau gesekkan antara umat Budha dan umat Konghucu di Belitung yang berkaitan dengan konsep-konsep ketuhanan dan simbol-simbol keagamaan yang dipakai oleh kedua agama tersebut. Masing-masing dari agama mereka mengkalim bahwa simbol tersebut adalah milik agama mereka. Namun dengan cara menekan riak komplik tersebut agar tidak menjadi besar dengan cara duduk bersama dan mencari solusi terbaik bersama akhirnya riak-riak tersebut menjadi hilang dan beribah menjadi rukun kembali.

Ketiga, melalui dialog. Dialog diadakan dengan cara mengumpulkan para tokoh agama disuatu tempat. Dalam diaolog ini dibicarakan tentang berbagai cara

\footnotetext{
${ }^{3}$ Beliau adalah Ketua FKUB Kabupaten Belitung sekaligus sebagai Sektretaris MUI Kabupaten Belitung.
} 
dan upaya untuk menciptakan kerukunan umat beragama yang ada di Kabupaten Belitung. Bahkan melalui dialog ini pula para tokoh bersama sama membuat zonasi komplik di Kabupaten Belitung, yakni menentukan zona Merah, Kuning dan Hijau. Jika zona merah berarti bahaya sekali dan dipastikan komplik, jika zona kuning baru rawan komplik, dan zona hijau aman dari komplik. Bahkan melalui dialog ini pula pada kahirnya berusaha untuk menciptakan kampung damai sebagai media percontohan bagi desa-desa yang lainnya.

Demikian pula hal nya yang dilakukan oleh H.Yuhanda di Koba Kabupaten Bangka Tengah, ia mengatakan bahwa dalam ajaran Islam hidup rukun dengan agama lain sudah dicontohkan oleh rasulullah saw ketika beliau hidup di Kota Madinah. Pada saat itu di kota madinah di huni oleh sekitar 10.000 orang yang terdiri dari 8500 non muslim seperti Yahudi, Nasroni, Majuzi, dan Musyrikiin sementara pemeluk agama islam hanya 1500 . Namun demikian, yang memimpin pada saat itu adalah umat Islam, yang dipimpin langsung oleh Rasulullah saw. Dalam kepemimpinannya beliau sangat disegani, dihormati bahkan dikagumi oleh semua umat beragama di Medinah. Hal ini disebabkan rasulullah tidak membedabedakan rakyatnya semuanya dimata rasulullah saw sama hal ini dibuktikan dengan diterbitkannya piagam madinah. Diantara sekian banyak isi piagam madinah yang ada hubungannya dengan toleransi adalah asas kebersamaan. Melalui asas ini Rasulullah saw membangun kota Medinah dengan tanpa membeda-bedakan suku, ras dan juga agama. Dengan kata lain, dimata Rasulullah saw dipandang sama semua masyarakat yang ada di kota Madinah.

Demikian halnya menurut $\mathrm{H}$. Bahtiar Harahap, toleransi antar umat beragama di Muntok sudah terjalin dengan baik sejak ratusan tahun yang lalu. Hal ini terbukti dengan adanya pembangunan rumah Ibadah yang berdampingan dikota Muntok antara bangunan Mesjid Jami' dan Klenteng. Berdasarkan informasi dari beliau bahwa pembangunan kedua tempat ibadah ini dibangun dengan cara gotong royong, khususnya waktu membangun Mesjid Jami' bahkan arsitenya saja didatangkan langsung dari Tionghoa dan bahan bangunannya didatangkan dari Belanda. Dengan demikian jelaslah bahwa warga muntok sejak ratusan tahun yang lalu sudah menunjukkan rasa toleransinya terhadap agama lain. Bahkan saat ini ada juga mesjid yang berdampingan dengan Greja. Oleh sebab itu, keduanya dijadikan simbol toleransi bagi para tokoh agama di Bangka Barat bahkan oleh para Tokoh Agama di Bangka Belitung, terutama adanya Mesjid Jami' dan Klenteng yang berdampingan sejak ratusan tahun yang lalu.

\section{Strategi Tokoh Agama Kristen Protentan}

Menurut Daniel ${ }^{4}$ strategi untuk membina umatnya agar memiliki rasa toleransi yang baik terhadap agama lain yaitu dengan cara diadakan pertemuan mingguan pada hari Minggu di Greja. Dalam pertemuan itu umat Protestan diajarkan tentang bagaimana kita bisa saling kasih mengasihi terhadap sesama khususnya terhadap umat agama yang lain. Hal ini seperti yang tercantumdalam

${ }^{4}$ Beliau adalah salah satu Pendeta (tokoh Agama Protestan) yang menjadi pengurus FKUB di Bangka Selatan 
kitab Injil yang mengatakan " lembutkan hatimu dengan segenap jiwamu dan kasihinilah sesamamu". Bahkan dijelaskan dalam ajaran protestan jangankan kawan, musuh saja harus dikasihi dengan istilahnya jika ditampar sebelah kiri maka kasih sebelah kanannya. Dalam pertemuan tersebut juga dibahas tentang masalah masalah keagamaan lainnya dan juga dibahas khusus saling menasehati tentang toleransi.

Begitu juga yang dikatakan Pendeta Heskia ${ }^{5}$ penganut sekaligus pendeta pada Agama Kristen Protestan Kharismatik, bahwa ajaran untuk rukun terhadap semua agama telah dijelaskan di Matius ajaran Yesus Kristus yang menyatakan "Kasihinilah sesama manusia". Bahkan dalam perjanjian lama diperintahkan agar memberkati kota, dimana kota aman maka semuanya aman. Adapun bunyi ayat dalam perjanjian lama yaitu "berdoalah bagi kotamu karena kesejahteraan kotamu adalah kesejahteraan kita". Dari dua ayat tersebut tersirat makna bahwa ajaran Protestan sangat menghargai orang lain, karena ketika diperintahkan untuk memberkati dan mendoakan kota atau daerah yang kita tempati berarti kita sedang menghargai dan menghormati kepada siapa saja atau agama apa saja yang ada dalam kota tersebut.

Menurut Bong Hiam $\operatorname{San}^{6}$ di Muntok Bangka Barat dari ratuan tahun yang lalu sampai saat ini belum pernah ada komplik sesama agama. Saat ini di Muntok kabupaten Bangka Barat agama Protentasn memiliki delapan Greja dan memiliki jamaah 700 orang. Agar terjaga kerukunan antar umat beragama maka yang selama ini dilakukan adalah kerjasama antar pendeta yang saat ini ada 11 pendeta dengan cara membuat acara bersama antar Greja untuk membina umat agar bisa rukun dengan agama lain. Sebab prinsipnya umat Protestan harus bersifat kasih sesama umat, kasih terhadap keluarga sesama greja, dan kasih terhadap sesama masyarakat. Hal ini dijelaskan dalam Al-kitab Injil yang berbunyi "Kasihinilah Tuhan Allah-mu, kasihinilah sesama seperti kamu mengasihi dirimu sendiri. Dengan katalain cubitlah dirimu dulu sebelum menyubit orang lain, jika sakit maka jangan sekali-kali menyakiti orang lain. Oleh sebab itu, sampai saat ini hubungan antara agama sudah snagat baik, terbukti dengan adanya Greja yang berdampingan dengan Mesjid di sungai Daeng Muntok.

\section{Strategi Agama Kristen Katolik Mendidik Toleransi Eksternal}

Menurut Forman Lumbandau ${ }^{7}$ di Bangka Selatan umat Kristen Katolik ada sekitar 170 Kepala Keluarga. Agar terjalin komunikasi dan hubungan yang baik dengan agama lain maka strateginya dengan cara diadakan pemahaman dan ajaran toleransi melalui khutbah-khutbah yang disampaikan di Greja. Dalam khutbah itu disampaikan ajaran kebersamaan, maksudnya kita harus memiliki rasa

\footnotetext{
${ }^{5}$ Beliau adalah salah satu Pendeta (Tokoh Agama Protestan) yang menjadi pengurus FKUB di Kabupaten Bangka Tengah.

${ }^{6}$ Beliau adalah salah satu Tokoh Agama Protestan yang menjadi Pengurus di FKUB Bangka Barat

${ }^{7}$ Beliau adalah salah satu Tokoh Agama Katolik yang menjadi Pengurus di FKUB Bangka Selatan
} 
kebersamaan dalam kehidupan. Dengan kebersamaan inilah akhirnya rasa benci dan rasa buruk sangka terhadap agama yang lainnya akan sirna akan tetapi berubah menjadi rasa kasih dan sayang serta cinta terhadap sesama. Selain menumbuhkan rasa kebersamaan, dalam khutbah juga disampaikan tidak boleh menghina atau menjelek-jelekkan agama yang lainnya. Sebab, masing - masing agama memiliki cara dan keyakinan yang berbeda-beda dalam beribadah. Ketika kita sudah bisa tidak menjelekkan agama yang lainnya berarti sebenarnya kita sudah menjalankan kebaikan menurut agama kita. Dengan demikian walaupun berbeda paham dan keyakinan dalam beragama akan tetapi harus bisa menghargai dan menghormati.

\section{E. Strategi Tokoh Agama Budha Mendidik Toleransi Eksternal}

Menurut Romo Budhy ${ }^{8}$ dalam ajaran Budha dimana ajaran kitab sucinya ada sebelum agama lain ada, sudah diajarkan tentang toleransi, diantara ajarannya bahwa tidak boleh menjelek-jelekkan agama lain. Hal ini memberikan makna bahwa ajaran Budha sangat menghargai ajaran agama lain, karena menghargai agama lain merupakan bagian dari ajaran yang mulia. Wujud dari mengahrgai itu dengan cara melarang umatnya untuk menjelek-jelekkan agama yang lain.

Memang harus diakui bahwa ajaran Budha dasarnya berasal dari agama Hindu. Namun demikian setelah jadi agama sendiri ajaran yang paling signifikan membedakannya yaitu ajaran yang tidak ada lagi kasta. Oleh sebab itu dalam ajaran Budha semua manusia sama yakni sederajat, dan semua mahluk berpotensi untuk menjadi Budha. Budha adalah gelar bagi orang yang sudah sadar, karena jika orang sudah sadar maka ia tidak akan lagi bersifat merugikan orang lain.

Ajaran untuk sadar inilah salah satu ajaran yang akhirnya dijadikan acuan untuk bisa menghargai orang lain, baik berupa ras, suku maupun agama. Melalui kesadaran ini maka umat Budha akan selalu memiliki sifat kasih sayang bukan saja kepada manusia akan tetapi kepada semua mahluk. Itulah sebabnya para Biksu tidak memakan makanan yang bersifat hewani, akan tetapi hanya memakan makanan nabati (vegetarian) hal ini dikarenakan dalam ajaran Budha tidak boleh menyakiti semua mahluk termasuk hewan. Artinya jika umat budha memakan makanan dari hewani berarti ia telah menyakiti hewan tersebut dengan cara menyembelihnya atau membunuhnya. Atas dasar inilah maka dalam ajaran Budha jangankan menyakiti manusia menyakiti hewan saja tidak boleh.

Romo Budhy selanjutnya mengatakan bahwa untuk menjaga kerukunan antar umat beragama paling tidak dengan tiga strategi yaitu : Pertama, Tanamkan jiwa humanis dalam setiap manusia. Berjiwa humanis artinya memiliki jiwa yang dipenuhi dengan rasa kasih sayang, rasa cinta terhadap sesama manusia. Melalui ajaran inilah akhirnya umat Budha masih diterima oleh masyarakat disekitarnya walaupun berbeda agama dan keyakinnya. Hal ini disebabkan umat Budha selalu menebarkan rasa kasih sayang dan cinta terhadap sesama manusia tidak memandang perbedaan suku maupun agamanya.

${ }^{8}$ Salah satu Tokoh Agama Budha atau sebagai pandeta yang tinggal di Tanjung Pandan Kabupaten Belitung, wawancara, 
Kedua, ajrakan ajaran agama yang inklusif bukan eksklusif. Ajaran inklusif adalah sebuah ajaran agama yang bisa membuka diri dengan ajaran agama yang lainnya. Artinya ditanamkan pada umat bahwa selain ajaran agama kita masih ada ajaran agama lainnya yang memiliki tatacara beragama yang berbeda akan tetapi ajaran humanisme nya sama. Sementara ajaran eksklusif adalah ajaran yang menutup erat erat pergaulan dengan agama lainnya. Sehingga ada ungkapan bahwa agama di dunia ini hanya agamanya saja.

Ketiga, melalui pendidikan di kelas-kelas darma. Hanya saja ajarannya lebih didominasi oleh aksi di lapangan atau praktek daripada teori. Memberikan dorongan untuk bisa memiliki kepedulian terhadap agama lain dan menjalankan kehidupan berdasarkan welas asih. Selalu berusaha meberikan perasaan bahagia terhadap orang lain dan berusaha mengangkat harkat orang lain bukan malah merendahkan. Bahkan dalam ajaran Budha ada nasehat yang bijak yaitu Bagi si miskin jangan melawan yang kaya, bagi si Kaya jangan melawan penguasa, dan bagi penguasa jangan merusak alam semesta dan merusak agama.

Intinya dalam ajaran Budha dan termasuk ajaran agama yang lainnya dipastikan tidak ada diajarkan untuk berkomplik akan tetapi dipastikan diajarkan untuk selalu memiliki rasa welas asih. Justru penyebab komplik itu adalah agama baru yang disebut dengan kapitalisme atau konsumerisme. Tempat ibadahnya di malla dan dipasar pasar, ritualitasnya belanja, mimbarnya club-club, dan Tuhannya adalah Duit. Agama inilah yang sering menimbulkan komplik dan menjadikan manusia menjadi pemarah, tega menyakiti dan mendzalimi orang lain dikarenakan agama baru tersebut berorientasi pada kesenangan duniawi.

\section{F. Strategi Tokoh Agama Hindu Mendidik Toleransi Eksternal}

Menurut I Wayan Pasek, umat Hindu di Belitung bisa rukun dengan Agama atau etnis lain karena memang dari awal datangnya sudah terbiasa hidup bersandingan dengan agama atau etnis lain. Hal ini sudah terjalin lama, bahkan dari sejak agama Hindu ada di Belitung. Hal ini diperkuat dengan ajarannya yang mengatakan " semua ciptaan Tuhan itu sama bahkan kita semua bersaudara (Wasu Dewa Kutum Baka dalam Kitab Weda). Dengan kata lain semua ciptaan Tuhan itu bersaudara yang membeda-bedakan adalah bukanlah Tuhannya akan tepi masingmasing dari para penganutnya (manusianya). Hal ini sesuai dengan uangkapan "Ta Tuong Masi yang artinya Aku adalah kamu dan Kamu adalah aku. Dengan demikian ketika kita menyakiti orang lain berarti kita sedang nenyakiti diri sendiri, atau dalam istilah lain dalam ajaran Hindu disebut dengan AHIMSA yang dipopulerkan oleh Mahatmagandi yang artinya tidak boleh berbuat kekerasan.

Berdasarkan beberapa ulasan ajaran Hindu di atas maka strategi yang baik agar terus terjalin kerukunan antara umat beragama yaitu saling menghargai terhadap keyakinan masing masing, dengan cara tidak boleh memaksakan agama lain untuk meyakini agama kita. Kedua, saling memahami bahwa agama itu banyak di indonesia dan setiap agama memiliki ajaran dan keyakinan yang berbeda. Ketiga, saling silaturrahmi baik ketika agama lain berhari raya maupun tidak. Bahkan wujud toleransi yang dilakukan oleh umat Hindu di Belitung, 
bukan saja terealisasi dalam bentuk kunjung mengunjungi akan tetapi lebih dari itu yaitu dengan adanya perkainan antar agama. Umat hindu ada yang nikah dengan umat Islam, nikah dengan umat Kristen, dengan umat Budha, dengan Umat Konghucu. Dengan demikian umat hindu sudah bisa menyatu dengan semua agama yang ada di Belitung.

\section{G. Mendidik Kerukunan Beragama antar Agama dengan Pemerintah}

Berdasarkan hasil wawancara dengan semua Tokoh Agama baik Islam, Kristen Protestan, Katolik, Budha, Hindu dan Konghucu, semuanya mengatakan bahwa selama ini dengan pemerintah memiliki kerukunan yang sangat baik. Hal ini terbukti dengan adanya kerjasama yang baik antara agama dengan pemerintah melalui pembangunan lembaga-lembaga pendidikan keagamaan dan rumah-rumah ibadah. Pemerintah tidak pilih kasih, semua agama dibantu untuk membangun rumah - rumah ibadah mulai dari mesjid, greja, vihara, pura dan juga klenteng.

Dalam ajaran Islam untuk baik dan taat kepada pemerintah secara tegas diajarkan dalam Al-Qur'an. Hal ini tertera dalam surat Annisa:59

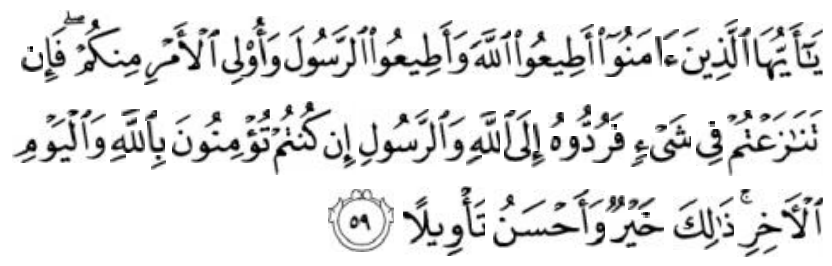

Hai orang-orang yang beriman, taatilah Allah dan taatilah Rasul (nya), dan ulil amri di antara kamu. Kemudian jika kamu berlainan pendapat tentang sesuatu, Maka kembalikanlah ia kepada Allah (Al Quran) dan Rasul (sunnahnya), jika kamu benar-benar beriman kepada Allah dan hari kemudian. yang demikian itu lebih utama (bagimu) dan lebih baik akibatnya.

Berdasarkan ayat ini jelaslah bahwa Allah memerintahkan kepada semua yang beriman agar taat pada Allah dan Rasulnya secara Mutlak, karena didahului dengan kata "Athi'uu" namun untuk taat pada pemerintah tidak mutlak akan tetapi bersyarat karena tidak didahului kata 'athi'uu". Artinya kemutlakan untuk taat pada pemerintah ketika pemerintah tersebut memang berada pada kebenaran, tetapi jika pemerintah berada dalam kesalahan dan kedzaliman maka ketaatan kita terhadap pemerintah menjadi tidak mutlak lagi, akan tetapi justru harus menasehatinya.

Dalam Agama Kristen Protestan berkaitan dengan ajaran baik tehadap pemerintah juga sangat dianjurkan. Hal ini seperti yang dikatakan oleh Heskia (pendeta) di Koba Bangka Tengah, ia mengatakan bahwa seluruh lembaga atau seluruh negara bisa ada dimuka bumi ini karena kehendak yang di atas (Allah). Bahkan dalam ajarannya ada perintah yang mengatakan "Hormatilah Rajamu, hormatilah pemerintahmu, yang akan memerintah kamu, meskipun tidak mengenakan kamu. Dengan demikian pahit atau manisnya keberadaan 
pemerintahmu saat ini maka tetap harus dihormati. Itulah sebabnya umat Protestan sampai saat ini tetap memiliki hubungan yang baik dengan pemerintah.

Begitu juga dengan agama Budha, selama ini seperti yang dikatakan Romo Budhy tokoh agama Budha di Tanjung Pandan Kabupaten Belitung, hubungan agamanya dengan pemerintah sangatlah baik. Bukti baiknya adalah ketika agama Budha membuat rumah Ibadah berupa Vihara pemerintah juga ikut andil dalam membangunnya dengan cara menyalurkan bnatuannya berupa dana hibah. Sehingga, sampai dengan saat ini hubungan agama Budha dengan pemerintah sangat baik.

Dalam agama Hindu juga demikian, menurut I Wayan Pasek, hubungan baik dengan pemerintah adalah kewajiban bagi setiap agama khususnya agama Hindu. Hal ini disebabkan kita hidup pun berada di wilayah kekuasaan pemerintahnya. Hubungan baik ini sudah pemerintah buktikan dengan adanya warga Bali yang semuanya beragama Hindu ditransmigrasikan di daerah Belitung. Semua fasilitas diberikan berupa sandang pangan dan papan, bahkan sekolah dan rumah ibadah pun di bantunya. Dengan demikian tiada kata lain bagi umat hindu di Belitung kecuali untuk selalu berbuat baik dan berhubungan baik dengan pemerintahnya.

Demikian juga dengan agama Konghucu, selama ini dirasakan hubungannya dengan pemerintah sangat harmonis. Hal ini terbukti walaupun umat konghucu hampir semuanya warga keturunan Tionghoa atau China akan tetapi telah diakui sebagai pribumi. Terlebih lagi pada masa Gusdur ada pengesahan langsung terhadap agama Konghucu yang menjadi kebanggaan sendiri bagi para penganutnya. Memang tidak dapat dipungkiri bahwa hubungan umat konghucu dengan pemerintah sempat tidak harmonis ketika masa orde baru apalagi setelah terjadi peristiwa G30 S PKI. Namun demikian akhirnya kembali harmonis sejak Gusdur mengakui agama Konghucu termasuk agama yang diakui di Indonesia.

\section{H. Konsep Kerukunan Bergama dalam Perspektif Kitab Suci Masing-Masing Agama}

Kerukunan sering dikenal dengan istilah populernya dengan sebutan toleransi. Sementara toleransi berasal dari kata Latin tolerare yang berarti bertahan atau memikul. Dengan demikian, toleran diartikan dengan saling memikul walaupun pekerjaan itu tidak disukai atau memberi tempat kepada orang lain, walaupun kedua belah pihak tidak sependapat. Berarti tidak ada yang namanya memaksakan kehendak sendiri atau kehendak orang lain supaya sesuai dengan kehendaknya masing-masing.

Persamaa kata toleransi dalam bahasa Arab adalah tasamuh yang berarti saling mengizinkan dan saling memudahkan. Artinya memberi ruang dalam hati kita untuk menerima perbedaan baik pendapat maupun pemikiran dari orang lain. Dengan demikian, toleransi berarti sikap menenggang, membiarkan, membolehkan, baik berupa pendirian, kepercayaan, dan kelakuan yang dimiliki seseorang atas yang lainnya. 
Pada pembahasan ini akan dijelaskan tentang toleransi atau konsep kerukunan yang ada pada setiap agama masing-masing. Hal ini disebabkan setiap agama memiliki konsep cinta, kasih sayang, dan perdamaian, sehingga menjadi pelopor terciptanya kehidupan yang damai dan hidup harmonis, saling menghormati, saling mencintai, dan saling menghargai hak dan kewajiban masingmasing. Bahkan, setiap agama memiliki kitab suci atau pedoman hidup yang semua berorientasi pada kebaikan, ketentraman dan keselamatan hidup yang diyakini oleh penganutnya masing-masing. Berati keinginan untuk hidup rukun dan damai ini merupakan ajaran universal yang di setiap agama ada tuntunannya. Untuk lebih jelas mengenai konsep kerukunan atau toleransi dalam pers[ektif agama masingmasing akan dijelaskan di bawah ini.

\section{Konsep Kerukunan atau Toleransi dalam Agama Islam}

Ketika Nabi Muhammad hijrah ke kota Madinah, Nabi melihat kenyataan adanya pluralitas agama. Di kota tersebut memiliki agama yang beranekaragam mulai dari agama Yahudi, agama Nasroni, Majuzi dan bahkan para Kaum Musyrikin lainnya yang tidak memiliki agama. Semua agama yang ada di kota Madinah saat itu diberikan kebebasan untuk memeluk dan mengamalkan ajarannya. Hal ini seperti yang tercantum dalam Pasal 25 Piagam Madinah menyebutkan bahwa bagi orang-orang Yahudi agama mereka dan bagi orang Islam agama mereka.Pasal 20 Piagam Madinah mengisyaratkan bahwa orang-orang musyrik atau kafir Madinah tidak dinyatakan sebagai musuh kaum Muslimin. Kebebasan beragama pada masa Nabi Muhammad s.a.w. juga ditunjukkan dengan adanya kebebasan dalam melakukan propaganda keagamaan.

Ajaran tentang kerukunan dalam Islam banyak dijelaskan dalam Al-Qur'an maupun Hadits Rasulullah saw. Dalam Al-Qur'an termaktub dalam beberapa surat dan ayat. Adapun yang tercantum dalam Al-Qur'an Al-Maidah 48, yaitu:

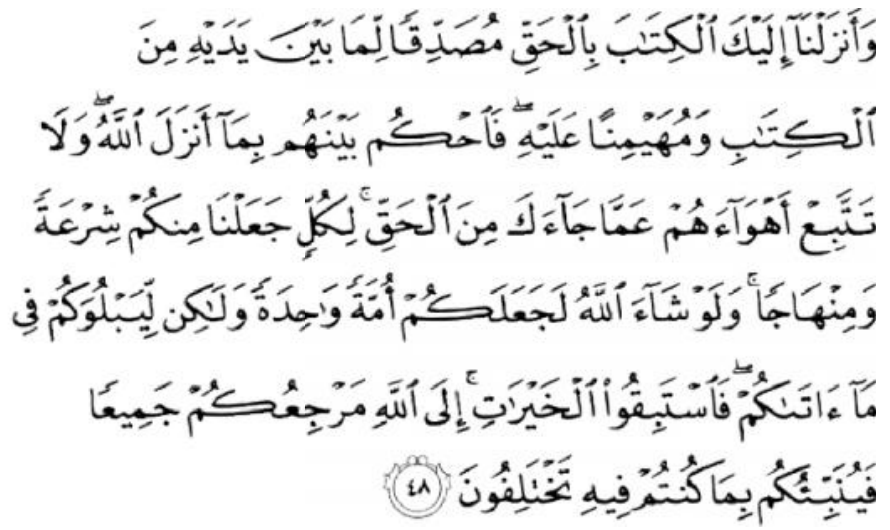

Dan kami Telah turunkan kepadamu Al Quran dengan membawa kebenaran, membenarkan apa yang sebelumnya, yaitu kitab-kitab (yang diturunkan sebelumnya) dan batu ujian terhadap kitab-kitab yang lain itu; Maka putuskanlah perkara mereka menurut apa yang Allah turunkan dan janganlah kamu mengikuti hawa nafsu mereka dengan meninggalkan kebenaran yang Telah datang 
kepadamu. untuk tiap-tiap umat diantara kamu, kami berikan aturan dan jalan yang terang. sekiranya Allah menghendaki, niscaya kamu dijadikan-Nya satu umat (saja), tetapi Allah hendak menguji kamu terhadap pemberian-Nya kepadamu, Maka berlomba-lombalah berbuat kebajikan. Hanya kepada Allah-lah kembali kaтu semuanya, lalu diberitahukan-Nya kepadamu apa yang Telah kamu perselisihkan itu.

Tercantum juga dalam Firman Allah Surat Al-Hujurat : 13

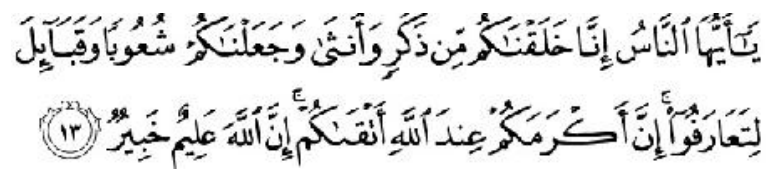

Hai manusia, Sesungguhnya kami menciptakan kamu dari seorang laki-laki dan seorang perempuan dan menjadikan kamu berbangsa - bangsa dan bersukusuku supaya kamu saling kenal-mengenal. Sesungguhnya orang yang paling mulia diantara kamu disisi Allah ialah orang yang paling taqwa diantara kamu. Sesungguhnya Allah Maha mengetahui lagi Maha Mengenal.

Tercantum juga dalam Al-Qyr'an Surat Ar-Rum:22

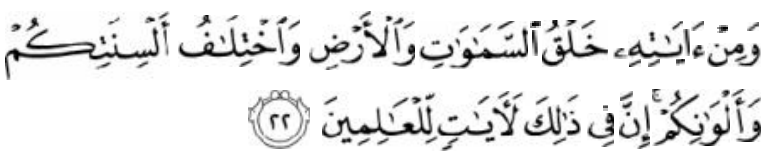

Dan di antara tanda-tanda kekuasaan-Nya ialah menciptakan langit dan bumi dan berlain-lainan bahasamu dan warna kulitmu. Sesungguhnya pada yang demikan itu benar-benar terdapat tanda-tanda bagi orang-orang yang Mengetahui.

\section{Bahkan dalam Hadits pun disebutkan :}

"Hai segenap manusia, sebarkanlah salam, sedekahkanlah makanan,dan sambunglah tali persaudaraan (silaturrahmi) serta shalatlah di kala manusia tidur di kegelapan malam, niscaya kamu masuk surga dengan penuh kedamaian” (HR. Tirmidzi).

Berdasarkan beberapa Ayat dan Hadits di atas memberikan makna bahwa Agama Islam mengajarkan agar umatnya untuk berbuat baik dan bertindak adil kepada siapapun yang tidak memerangi umat Islam karena agama yang dianut. Islam mengutamakan terciptanya suasana perdamaian, 
hingga timbul rasa kasih sayang di antara umat Islam dengan umat beragama lain .Kerjasama yang baik antara umat Islam dan umat beragama lain tidaklah menjadi halangan dalam Islam. Hal ini disebabkan Islam diturunkan bukan saja rahmat bagi umat Islam akan tetapi harus juga menjadi rahmat bagi seluruh alam. Hal ini sesusi dengan Firman Allah dalam Al-Qur'an yang artinya: “Dan tidaklah aku utus engkau wahai Muhammad kecuali sebagai rahmat bagi seluruh alam”.

\section{Konsep Kerukunan dalam Persfektif Agama Hindu}

Kemajemukan atau keberagaman bukan hanya sebagai sebuah realitas sosial. UUD 1945 menyatakan dgn jelas bahwa negara menjamin kemerdekaan tiap-tiap penduduk untuk memeluk agamanya masing-masing dan untuk beribadat menurut agama dan kepercayaannya. Karena itulah ditegaskan bahwa semua agama memiliki hak yang sama untuk tumbuh dan berkembang, termasuk pemeluknya untuk menjalankan agamanya secara bebas. Pemeluk agama tertentu tidak boleh memaksa pemeluk agama lainnya untuk pindah agama sebagaimana realita yang kita lihat selama ini. Setiap orang memiliki hak dasar untuk memeluk agama yang berarti kebebasan dan kewenangan seseorang untuk menganut suatu agama yang tercantum dalam Pustaka Suci Veda, khususnya Bhagavadgita.

Umat Hindu menghormati kebenaran dari manapun datangnya dan menganggap bahwa semua agama bertujuan sama, yaitu menuju Tuhan, namun dengan berbagai sudut pandang dan cara pelaksanaan yang berbeda. Hal ini diuraikan dalam Bhagavadgita IX.29 yang berbunyi:

samo 'ham sarvabhuutesu

na me dvesyo 'sti na priyah

ye bhajanti tu maam bhaktyaa

mayi te tesu caa 'py aham

Artinya : Aku bersikap adil pada semua makhluk, tidak ada yang paling Ku-benci ataupun yang paling Ku-kasihi, akan tetapi mereka yang berbhakti kepada-Ku, maka dia ada dalam Diri-Ku dan Aku ada dalam dirinya.

Begitu pula Bhagavadgita IV.11 yang menyatakan

ye yathaa mam prapadyante

tams tathaiva bhajamy aham

mama vartmanuvartante

manusyah partha sarvasah 
Jalan manapun yang ditempuh seseorang mendekati-Ku, Aku terima, melalui banyak jalan manusia mengikuti jalan-Ku, wahai Arjuna.

Selanjutnya Bhagavadgita VII.21 juga menyatakan:

yo-yo yam-yam tanum bhaktah

sraddhayarcitum icchati

tasya-tasya calam sraddham

tam eva vidadhamy aham

Apapun bentuk pemujaan yang ingin dilakukan oleh para bhakta dengan penuh keyakinan, Aku menjadikan bentuk keyakinannya itu menjadi mantap.

Pandangan Hindu tentang kebhinekaan dan kewarganegaraan juga tertuang dalam Kitab Sutasoma karya Mpu Tantular pada jaman Majapahit saat pemerintahan Raja Hayam Wuruk. Dalam kitab ini terdapat ungkapan yang dipetik oleh para pendiri bangsa yaitu pada pupuh 139 (bait V) yang dijadikan motto dalam Garuda Pancasila sebagai lambang Negara Kesatuan Republik Indonesia, yang selengkapnya berbunyi:

hyang buddha tanpahi siwa rajadewa rwaneka dhatu winuwus buddha wiswa bhineki rakwan ring apan kena parwanesen mangkana jiwatman kalawan siwatattwa tunggal bhinneka tunggal ika tan hana dharma mangrwa

Artinya : Hyang Buddha tiada berbeda dengan Siwa Mahadewa, keduanya merupakan sesuatu yang satu, tiada mungkin memisahkan satu dengan lainnya, berbeda keadaannya namun satu jua adanya, karena tiada kebenaran yang mendua.

Semboyan "bhinneka tunggal ika" yang telah ditorehkan pada Garuda Pancasila sebagai lambang NKRI telah menginspirasi banyak orang bahwa sesungguhnya umat manusia di Indonesia dapat dipersatukan dalam wadah keberagaman. Atharwaweda VII.52.1 yang berbunyi

Samjnanam nah svebhih samjnanam aranebhih, samjnanam asvina yuvam ihasmasu ni yacchatam

Artinya: Hendaknya harmonis diantara kamu baik dengan orang-orang yang dikenal maupun dengan orang asing sekalipun. Semogalah Dewa Asvin memberikan anugerah untuk keharmonisan.

Bahkan Hindu memandang bahwa orang hina dan binatang sekalipun adalah sama, sebagaimana dinyatakan dalam Bhagavadgita V.18:

vidya vinaya sampanne 
brahmane gavi hastini

suni caiva svapake ca

panditah sama darsinah

Artinya: Orang bijaksana melihat semuanya sama, baik dalam melihat brahmana budiman nan rendah hati maupun seekor sapi, gajah, dan anjing ataupun orang yang rendah sekalipun.

Selain itu, Hindu dikenal istilah santa jagadhita atau sukritama, yaitu masyarakat religius yang hidup dalam kedamaian dan ketenteraman. Dalam Kitab Weda dikatakan "Wahai umat manusia! Bersatulah dan rukunlah kamu seperti menyatunya para dewata. Aku telah menganugerahkan hal yang sama kepadamu. Oleh karena itu, Ciptakanlah persatuan di antara kamu” (Atharvaveda III.30.4).

\section{Konsep Kerukunan Dalam Persfektif Agama Budha}

Wahai umat manusia! Milikilah perhatian yang sama. Tumbuhkan saling pengertian di antara kamu. Dengan demikian engkau dapat mewujudkan kerukunan dan kesatuan” (Rigveda X. 191.4).

Agama Buddha juga cinta perdamaian, Untuk mewujudkan perdamaian, Buddha memiliki konsep metta, yakni cinta kasih universal. Metta lebih luas dan lebih mulia dari semua bentuk persaudaraan yang sempit. Metta tidak dibatasi oleh peraturan-peraturan, bidang-bidang; tidak mempunyai rintangan dan penghalang; tidak mengadakan perbedaan.

Sabda Sang Buddha:"Segala keadaan kita adalah hasil dari apa yang kita pikirkan. Dijadikan oleh pikiran kita dan ditentukan oleh pikiran kita. Kalau kita berkata dan berbuat dengan pikira positif, yakni pikiran yang penuh dengan cinta kasih, belas kasihan dan simpati terhadap kebahagiaan orang lain, adil dan bijaksana, maka kebahagiaan dan kedamaian akan senantiasa mengikuti kita"

Seorang yang berada di tengah-tengah orang yang membenci, hendaklah orang itu hidup bebas dari kebencian".

"Kebencian tidak akan berakhir kalau dibalas dengan kebencian. Kebencian akan berakhir kalau dibalas dengan cinta kasih atau dengan tidak membenci”.

"Kebencian tak dapat dipadamkan dengan kebencian. Hanya sikap tidak membenci yang dapat mengakhirinya. Inilah hukum yang abadi” (Dhammapada, $\mathrm{I}: 5)$.

\section{Konsep Kerukunan dalam Perspektif Agama Kristen}

Dalam Kristen, ada keyakinan bahwa Yesus adalah tokoh cinta damai dan anti kekerasan. Karena Yesus adalah pembawa damai, maka umat Kristiani juga terpanggil untuk menjadi pembawa damai. Dalam hal ini Yesus bersabda:

"Berbahagialah orang yang membawa damai karena mereka akan disebut anak-anak Allah" (Matius 5:8). 
Menurut Daniel Tokoh Agama Kristen di Bangka Selatan, mengatakan bahwa jika semua umat mengamalkan ajaran agamanya masing-masing termasuk didalamnya umat kristen dipastikan tidak akan ada pertikaian antara umat bergama. Apalagi dalam agama Kristen seperti yang diungkapkan dalam Matius 5:8 orang yang membawa kedamaian maka termasuk anak-anak Allah.

\section{Strategi Tokoh Agama dalam Menjaga Keutuhan NKRI di Babel}

1. Konsep agama tentang cinta pada negara

Berdasarkan hsil wawancara pada setiap tokoh Agama, mereka sepakat bahwa tiap ajara agamanya memiliki konsep untuk mencintai negaranya. Dalam ajaran Islam para ulama Nusantara menanamkan rasa nasionalisme pada umatnya dengan slogan "Hubbul Wathan Minal iiman (cinta tanah air bagian dari iman. Hal ini memiliki makna tersirat bahwa jika seseorang tidak memiliki rasa cinta terhadap negaranya maka berarti ada sebagain imannya yang kurang.

Dalam umat Islam cinta Tanah air ini telah terbukti ketika masa penjajahan. Semua ulam dan para santrinya berjuang dengan segenap jiwa dan raganya demi mebela negaranya. Turunnya para ulama dan semua sntrinya untuk berjuang melawan penjajahan dimuka bumi indonesia inilah sebagai bukti bahwa cinta tanah air itu bagian dari Iman. Sehingga banyak dari pahlawan negara yang berasal dari umat Islam, seperti Pangeran Diponegoro, Jendral Sudirman, Tuanku Imam Bonjol, Cut Nyakdien, Bung Tomo, Sultan Hasanudin dll.

Dalam Agama Kristen ajaran untuk mencintai negaranya pun tertcantum adalam kitabnya. Hal ini diunhkapkan bahwa setiap umat kristen harus menghormati pemerintah dan negaranya. Adapun perintah itu berbunyi " hormatilah rajamu, hormatilah pemerintahmu yang akan memerintahmu walaupun tidak mengenakkan kamu". Disinilah akhirnya umat kristen selalu berusaha untuk menghormati pemerintah, ketika menghormati pemerintah berarti mencintai juga tempat yang dperintahnya yaitu negara.

\section{Strategi Tokoh agama dalam mempertahankan NKRI}

Semua Tokoh Agama sepakat NKRI akan tetap ada jika falsafah negara berupa pancasila masih tetap dipertahankan. Selama ini telah terbukti bahwa pancasila dapat menyatukan bukan hanya semua suku ras dan etnis akan tetapi juga agama. Bahkan menurut agama hindu bahwa istilah pancasila tersebut berasal dari bahasa agama mereka, begitu juga dengan semboyan Bhineka Tunggal Ika. Oleh sebab itu, selama pancasila masih dijadikan falsafah negara maka para tokoh agama optimis NKRI akan tetap bisa dipertahankan atau masih utuh. Namun 
demikian, jika falsafah ini dirubah kemungkinan darisinilah berawal perpecahan diantara suku dan agama akan terjadi.

Selain itu, semua agama merasakan bahwa NKRI adalah milik bersama yang harus dijaga keutuhannya. Sebab, bisa jadi saat ini ada beberapa oknum yang tidak menginginkan NKRI ini utuh, sehingga mereka membuat makar atau propaganda adu domba dimana-mana. Tentunya tujuan akhirnya menginginkan NKRI ini terpecah bahkan mungkin dihancurkan agar tidak bersatu lagi.

Atas dasar inilah maka semua para tokoh agama di Bangka Belitung, memiliki persepsi yang sama tentang menjaga keutuhan NKRI. Adanya FKUB termasuk salah satu media untuk menjaga keutuhan NKRI agar persatuan dan kesatuan tetap terjaga. Sebab, FKUB ini dibentuk untuk menyatukan seluruh persepsi agama yang ada di Bangka Belitung.

\section{J. Penutup}

Strategi para Tokoh agama dalam menjaga kerukunan beragama di Bangka Belitung terdiri dari tiga;

Pertama, strategi mendidik umat dalam kerukunan internal umat beragama. Dalam hal ini semua para tokoh agama masing-masing sepakat membina umatnya agar hidup rukun dan damai. Tentunya arahan ini sesuai dengan ajaran kitabnya masing-amsing.

Kedua, strategi mendidik umatnya agar rukun dengan sesama agama yang lainnya. Mereka berusaha maksimal agar setiap uamtnya selalu menghargai dan menghormati agama yang lainnya, tidak boleh mamaksa kehendak agamanya, tidak boleh saling menjelek-jelekkan gama yang lain dan juga tidak boleh menyakiti umat agama lainnya. Hal ini pun tercantum dalam jarannya kitab suci disetiap agama masing-masing.

Ketiga, strategi mendidik umatnya agar rukun dengan pemerintah. Dari hasil wawancara disimpulkan bahwa semua ajaran agama memerintahkan agar selalu berhubungan baik dan menghormati pemerintahnya. Hal ini disebabkan semuanya menyadari bahwa kita hidup dinegara yang sama yaitu negara Indonesia dalam satu kekuasaan dan pemerintahan. Maka menghormati, menghargai dan mamtuhi aturan pemerintah adalah sebuah keharusan

Strategi untuk menjaga keutuh NKRI juga disepakati oleh semua tokoh agama. Mereka sepakat jika faLsafah Indonesia adalah Pancasila, jangan dirubah lagi. Hal ini disebabkan selama ini yang dapat menyatukan semua ajaran agama yang ada di Indonesia adalah Pancasila. Untuk itu NKRI menjadi utuh dan akan tetap utuh jika semua agama menjaga pancasila. 


\section{Daftar Pustaka}

Heri herdiawanto dan Jumanta Hamdayama, Cerdas, Kritis, dan Aktif Berwarganegara, Jakarta: Erlangga, 2010

Nurcholish madjid, Islam Kemodernan dan Keindonesiaan, Bandung: PT. Mizan Pustaka, 2008

Durkheim, Emile 1993, Dasar-Dasar Sosial Agama dalam Roland Robertson (ed) Agama dalam Analisa dan Interpretasi Sosiologis. Terjemahan A.F. Saifuddin, Jakarta: Rajawali Press.

Machasin, 2011, Islam Dinamis Islam Harmonis Lokalitas Pluralisme Terorisme, Yogyakarta: LKiS.

Hasan, Noorhaidi, 2012, dakwah, aktivitas diskursif dan tantangan globalisasi, Jakarta: Puslitbang Kehidupan Keagamaan Kemenag RI.

Herdiawanto, Heri dan Hamdayama, Jumanta, 2010, Cerdas, Kritis, dan Aktif Berwarganegara, Jakarta: Erlangga.

http://www.kemendagri.go.id/pages/profil-daerah/provinsi/detail/19/kepulauanbangka-belitung

Kymlicka, Will, 1995, Multicultural Citizenship. A Liberal Theory of Minority Rights, Oxford: Oxford University Press.

Muhaimin, MA. Et al. 2007, Kawasan dan Wawasan Studi Islam, Jakarta: Kencana. 
|SUPARTA| Strategi Para Tokoh Agama dalam Mendidik...

66 | EDUGAMA Vol. 4 No. 1 Juli 2018 